\title{
STRATEGI PENERAPAN E-GOVERNMENT PADA UPT TEKNOLOGI DAN KOMUNIKASI PENDIDIKAN DINAS PENDIDIKAN PROVINSI RIAU
}

\author{
Pebriana Marlinda \\ Fakultas Ilmu Administrasi Universitas Lancang Kuning \\ pebriana@unilak.ac.id
}

\begin{abstract}
Abstrak
Penerapan e-government pada UPT Teknologi dan Komunikasi Pendidikan Dinas Pendidikan Provinsi Riau sudah terlaksana sejak lama, namun dalam penerapannya belum berjalan dengan baik. Kenyataan yang terjadi yaitu pemahaman dalam pemanfaatan e-government yang hanya sebatas penyediaan web site. Pada saat sekarang ini web site tersebut dalam keadan tidak beroperasi dikarenakan adanya kerusakan pada perangkat IT atau infrastruktur yang ada. Metode penelitian yang digunakan yakni metode kualitatif dengan pendekatan deskriptif. Hasil penelitian menunjukkan bahwa strategi penerapan e-government yang dilakukan UPT Teknologi dan Komunikasi Pendidikan Dinas Pendidikan Provinsi Riau belum berjalan sebagaimana yang diharapkan, dikarenakan kurangnya sosialisasi dan pelatihan - pelatihan mengenai teknologi informasi dan komunikasi dibidang pendidikan.
\end{abstract}

Kata Kunci: Strategi dan e-Government

\section{A. PENDAHULUAN}

Penerapan e-Government bukanlah sesuatu yang sederhana yang hanya memanfaatkan komputer atau otomatisasi terhadap prosedur yang ada. Memang benar bahwa komputerisasi dan otomatisasi prosedur harus dilakukan. Namun lebih dari merubah mentalitas para birokrat meningkatkan layanan masyarakat dan partisipasi masyarkat harus menjadi fokus utama penerapan $e$ government dan teknologi hanyalah sebuah alat. Oleh karenanya perlu ditempuh cara penerapan secara gradual dan berkelanjutan dimulai dari proses transparansi, akuntabel, adil (fair), efektif, efisien, dinamis dan disesuaikan dengan kebutuhan instansi yang akan menerapkannya.

E-Government bukan sekedar menyediakan pelayanan online akan tetapi lebih luas dari pada itu, karena kinerja pada sektor publik juga akan berkontribusi pada kemajuan ekonomi dan sosial suatu negara. Dengan denikian dapat dikatakan bahwa pendayagunaan e-Government ditujukan untuk mendukung terwujudnya pemerntahan yang baik (Good Government). Pendayagunaan $e$ government ini diharapkan dapat meningkatkan pelayanan publik kepada masyarakat dalam administrasi pemerintahan dan dapat mengurangi kesenjangan informasi antara pusat dan daerah. E-Government secara keseluruhan dapat meningkatkan transparansi dan akuntabilitas para penyelenggara pemerintahan serta menciptkan lingkungan tata pemerintahan baru yang mampu menjawab berbagai permasalahan yang 
dihadapi sebagai akibat dari kecenderungan perubahan global. Dengan diterapkannya e-Government masyarakat juga akan semakin mudah berinteraksi dengan satuan-satuan dalam pemerintahan sehingga tercipta mekanisme kebijakan dan pelayanan publik yang terbuka dan demokratis.

Hal-hal tersebut membuat $e$ Government seolah menjadi sebuah trend global yang sangat populer di birokrasi-birokrasi di seluruh dunia untuk pelaksanaannya dalam sistem pemerintahan. Sebagai contoh dapat dilihat dalam perkembangan pelayanan publik di Pemerintahan Indonesia saat ini. Pemerintah pusat dan merintah daerah seolah-olah berlomba untuk melakukan pengembangan aplikasi $e$ government, yaitu pelaksanaan pemerintahan berbasis teknologi informasi yang telah menjadi tuntutan dalam upaya memenuhi tugas-tugas pelayanan publik yang membutuhkan kecepatan, ketepaan dan penaganan permasalahan yang dapat diselesaikan secara cepat dan secara lintas sektoral.

Dalam perkembangan, $e$ government yang berjalan saat ini masih berfokus pada penyedian web site dan layanan informasi. Sehingga muncul opini publik bahwa suatu instansi pemerintah sudah menerapkan $e$ government ketika sudah memiliki web site. Sedangkan konsep e-Government pada hakikatnya tidak hanya menampilkan informasi pemerintahan melalui web site, namun dari aspek transparansi dan akuntabiliitas hubungan antara pemerintah dengan seluruh stakeholder sudah mulai migrasi dari asalnya menggunakan media konvensional sudah beralih kepada media digital (internet). Pemahaman $e$ government secara sempit tersebut menyebabkan kurang optimalnya pemanfaatan teknologi informasi dilingkungan pemerintahan. Sebagaimana situs pemerintah pada umumnya yang memberikan layanan informasi. Fenomena ini terjadi pada Unit Pelaksanaan Teknis (UPT) Teknologi dan komunikasi Pendidikan Dinas Pendidikan Provinsi Riau.

UPT Teknologi dan Komunikasi Pendidikan Dinas Pendidikan Provinsi Riau merupakan bagian dari Dinas Pendidikan Provinsi Riau yang mempunyai visi yaitu "terwujudnya lembaga pendidikan Provinsi Riau yang mampu menghasilkan sumber daya manusia berkualitas, beriman dan bertaqwa serta memiliki daya saing tahun 2020”. Dinas Pendidkan Provinsi Riau memiliki sebuah Web Site dengan alamat http/btpdisdik.riau.go.id.

UPT Teknologi dan Komunikasi Pendidikan Dinas Pendidikan Provinsi Riau memiliki misi yang salah satu dari misinya yaitu menerapkan program Jardiknas. Jardiknas merupakan salah satu program pusat yang berupa pelayanan dibidang pendidikan dengan menggunakan jaringan internet. Pada saat sekarang ini web site yang dimiliki Dinas Pendidikan Provinsi Riau yang di Kelolah oleh UPT Teknologi dan Komunikasi Pendidikan Dinas Pendidikan Provinsi Riau sering tidak dapat beroperasi, diakrenakan kerusakan pada perangkat IT atau infrastruktur yang ada. Disamping itu informasi yang diberikan tidak up to date dan masih bersifat satu arah. Berdasarkan fenomena - fenomena yang ditemukan peneliti di lapangan, maka penelti tertarik untuk melakukan penelitian dengan judul "Strategi Penerapan $e$ Government Pada UPT Teknologi dan 
Komunikasi Pendidikan Dinas Pendidikan Provinsi Riau".

\section{B. KONSEP TEORITIS}

1. Strategi Chandler dalam Rangkuti (200 :4) menyebutkan bahwa "Strategi adalah tujuan jangka panjang dari suatu perusahaan/organisasi, serta pendayagunaan dan alokasi semua sumber daya yang penting untuk mencapai tujuan ". Lebih lanjut teori ini menekankan pada 2 hal yaitu sebagai berikut:

a. Distinctive Competence

Merupakan tindakan yang dilakuakn perusahaan /organisasi agar dapat melakukan kegiatan lebih baik dibandingkan dengan pesaingnya. Suatu perusahaan/organisasi yang memiliki kekuatan yang tidak mudah ditiru oleh perusahaan/organisasi pesaing dipandang sebagai perusahan yang emmilki Distintinctive Competence". Distintinctive Competence menjelaskan kemampuan spesifik suatu organisasi.

b. Competitive Advantage

Merupakan kegiatan spesifik yang dikembangkan oleh perusahaan/organisasi agar lebih unggul dibandingkan pesaingnya. Keunggulan bersaing disebabkan oleh pemilihan strategi yang dilakukan oleh perusahaan untuk merebut peluang pasar.

Dari definisi diatas dapat diketahui bahwa strategi merupakan suatu cara agar suatu instansi atau organisasi agar mencapai tujuannya. Dalam hal ini UPT Teknologi dan Komunikasi Pendidikan Dinas Pendidikan Provinsi Riau telah membuat strategi dalam penerapan $e$ government bidang pendidikan yaitu sebagai berikut.

1. Menerapkan pendekatan partisipatif
2. Mengelola program dsan kegiatan yang transparan

3. Menerapkan akuntabilitas

4. Menerapkan prinsip kerja magang

5. Mengadakan pelatihan

6. Menjalin kerja sama

Strategi tersebut diatas dibuat oleh UPT Teknologi dan Komunikasi Pendidikan Dinas Pendidikan Provinsi Riau dalam rangka agar terlaksananya penerapan e-goverment di lingkungan Pemerintahan Provinsi Riau sebagai salah satu wujud dalam peningkatan mutu pendidikan di Provinsi Riau.

\section{E-Government}

Merujuk dari INPRES No. 3 Tahun 2003 Tentang Kebijakan dan Strategi NASIONAL Pengembangan $E$ Government di Indonesia merupakan upaya untuk mengembangkan penyelenggaraan kepemerintahan yang berbasis elektronik dalam meningkatkan kualitas layanan publik secara efektif dan efisien. Pengertian umum $e$ government adalah penyelenggaraan pemerintahan berbasis elektronik (teknologi informasi dan komunikasi) untuk meningkatkan kinerja pemerintah dalam hubungannya dengan masyarakat, komunikasi bisnis dan kelompok terkait lainnya menuju good governance.

Caldow dalam Indrajit (2006 : 192) mendefinisikan e-Government adalah pemanfaatan Teknologi Informasi dan Komunikasi (TIK) guna pelaksanaan pemerintahan yang efisien dan murah, dengan meningkatkan pelayanan masyarakat dengan cara menyediakan sarana publik sehingga masyarakat mudah mendapatkan informasi, dan menciptakan pemerintahan. E-Government merupakan penggunaan teknologi informasi oleh pemerintah (seperti: Wide Area Network, Internet dan mobile 
computing) yang memungkinkan pemerintah untuk mentransformasikan hubungan dengan masyarakat dunia bisnis dan pihak yang berkepentingan.

\section{KERANGKA BERFIKIR}

Dari uraian pada pendahuluan dan konsep teoritis maka peneliti merumuskan kerangka pemikiran dalam penelitian ini yakni sebagai berikut.

GambarKerangka Pemiliran
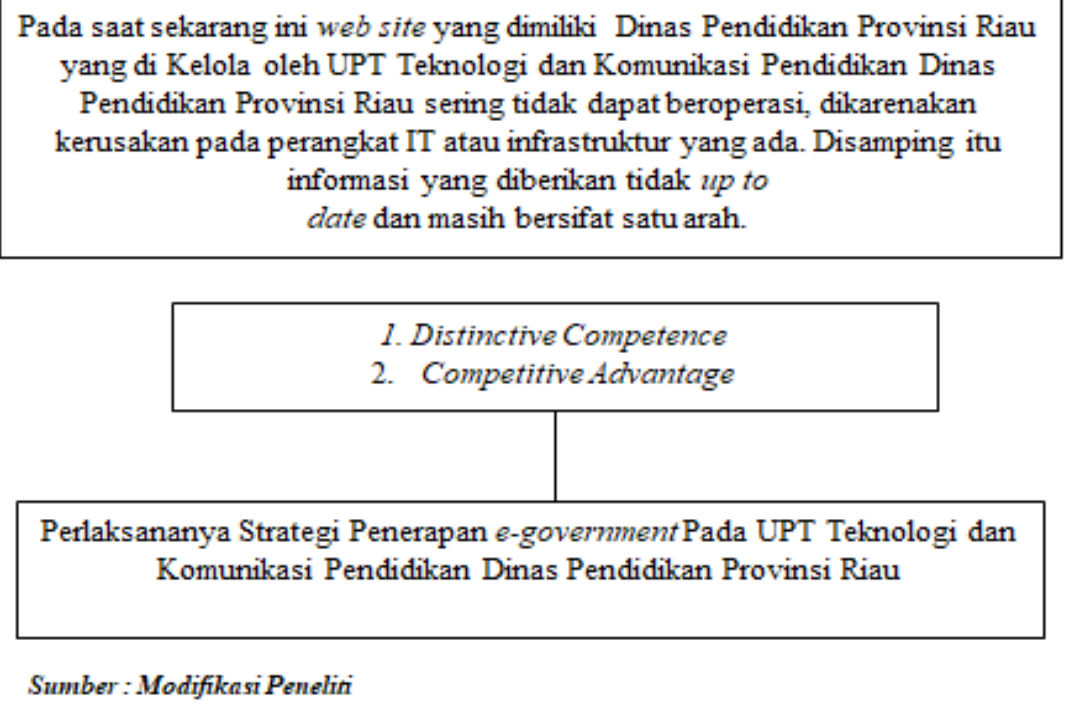

\section{METODE PENELITIAN}

Metode penelitian yang digunakan yakni metode penelitian kualitatif dengan pendekatan deskriptif. Metode ini merupakan suatu cara yang digunakan dalam penelitian untuk menjawab permasalahan penelitian yang dilakukan dalam hal ini yaitu terkait pemecahan permasalahan strategi penerapan e-Government pada UPT Teknologi Dan Komunikasi Pendidikan Dinas Pendidikan Provinsi Riau, setelah data itu diperoleh maka akan diklasifikasikan dan tahapan selanjutnya akan di analisis dengan pendekatan deskriptif. Menurut Craswell (2002 : 1) menjelaskan bahwa penelitian kualitatif merupakan sebuah proses penyelidikan untuk memahami masalah sosial atau masalah manusia, berdasarkan pada penciptaan gambaran holistik lengkap yang dibentuk dengan kata - kata, melaporkan pandangan informan secara terperinci, dan disusun dalam sebuah latar ilmiah. selanjutnya, untuk menganalisis data penelitian peneliti menggunakan model analisis data Miles and Humberman. Miles and Huberman (1992), mengemukakan bahwa aktivitas dalam analisi data kualitatif dilakukan secara interaktif dan berlangsung secara terus menerus sampai tuntas, sehingga datanya sudah jenuh. Aktivitas dalam analisis data, yaitu data reduction, data display, dan conclusion drawing/verification. berikut gambar dari model teknik analisis data Miles and Humberman. 


\section{Gambar : Teknik Analisis Data Miles and Huberman}

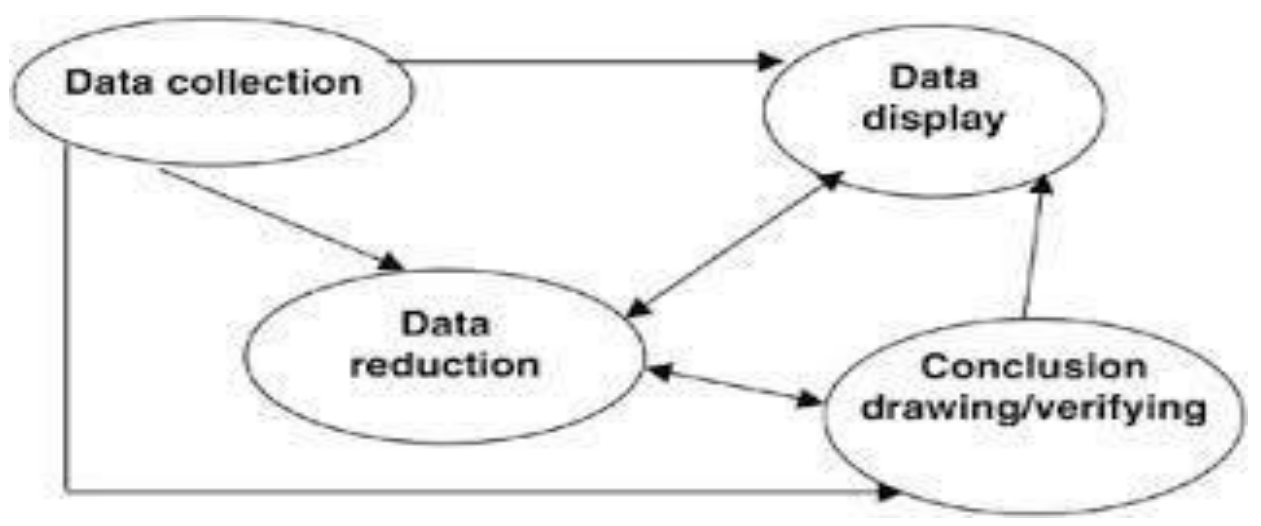

\section{E. PEMBAHASAN}

UPT Teknologi dan Komunikasi Pendidikan merupakan bagian dari Dinas Pendidikan Provinsi Riau yang menangani pelaksanaan teknis dinas dalam bidang pengembangan dan pendayagunaan teknologi informasi dan komunikasi pendidikan. Untuk menjamin terlaksananya program kegiatan UPT Teknologi dan Komunikasi Pendidikan serta tercapainya tujuan, maka disusunlah strategi sebagai berikut:

1. Menerapkan pendekatan partisipatif

2. Mengelola program dsan kegiatan yang transparan

3. Menerapkan akuntabilitas

4. Menerapkan prinsip kerja magang

5. Mengadakan pelatihan

6. Menjalin kerja sama

Strategi diatas dirumuskan agar tercapainya tugas pokok dan fungsi UPT Teknologi dan Komunikasi Pendidikan Dinas Provinsi Riau yang merupakan bagian dari penerapan e-government yaitu mengembangkan dan mendayagunakan teknologi informasi dan komunikasi untuk pendidikan, mengembangkan dan memberdayakan sekolah, tenaga pendidikan dan kependidikan dalam bidang teknologi informasi dan komunikasi sehingga mutu pendidikan dapat ditingkatkan. Untuk itu peneliti akan menganalisis strategi penerapan e-government yang laksanakan oleh UPT Teknologi dan Komunikasi Pendidikan Dinas Provinsi Riau melalui teori yang dikemukakan oleh Chandler dalam Rangkuti (2006 : 4), dimana strategi suatu organisasi dilihat dari Distinctive Competence dan Competitive Advantage yaitu sebagai berikut.

\section{Distinctive Competence}

Distinctive Competence merupaka tindakan yang dilakukan oleh suatu organisasi yang berbeda dengan organisasi lainnya agar menjadi sebuah organisasi yang unggul dari organisasi lainnya. Dalam hal ini yaitu tindakan dalam penerapan e-government yang dilakukan oleh UPT Teknologi dan Komunikasi Pendidikan Dinas Pendidikan Provinsi Riau. Sebagaimana yang telah dijelaskan sebelumnya bahwa tugas pokok dan fungsim UPT Teknologi dan Komunikasi Pendidikan Dinas Pendidikan Provinsi Riau yang merupakan bagian dari penerapan $e$ - 
government yaitu pengembangan dan pendayagunaan teknologi informasi dan komunikasi untuk pendidikan di sekolah untuk tenaga pendidik dan kependidikan dalam bidang teknologi informasi dan komunikasi sehingga mutu pendidikan dapat ditingkatkan.

Berdasarkan pengamatan peneliti tidak langkah-langkah yang diambil oleh UPT Teknologi dan Komunikasi Pendidikan Dinas Pendidikan Provinsi Riau belum menunujkkan hasil sebagaimana mestinya. Sebagai contohnya dalam masalah web site Dinas Pendidikan Provinsi Riau sering kali dalam keadaan error. Keadaan ini otomatis menghambat penyebarluasan sistem model pembelajaran berbasis teknologi informasi dan momunikasi melalui pendayagunaan dan pemanfaatan program PUSAT seperti : Jardiknas, Telconfrence dan e-learning.

\section{Competitive Advantage}

Competitive Advantage merupakan kegiatan mendasar yang dilaksakan oleh UPT Teknologi dan Komunikasi Pendidikan Dinas Pendidikan Provinsi Riau, adapun kegiatan yang dimaksud yaitu kegiatan pelatihan. Pelatihan sangatlah diperlukan sebelum menerapkan suatu program, dalam hal ini yaitu sebelum menerapkan $e$ government. Pelatihan ini merupakan bagian dari sosialisasi untuk mencapai tujuan dari program dan kegiatan yang akan diterapkan, juga berguna untuk menyamakan persepsi antara pihak pelaksana dengan pihak sasaran dari program tersebut. Pelatihan biasanya diadakan oleh pihak UPT Teknologi dan Komunikasi Pendidikan Dinas Pendidikan Provinsi Riau dan pemerintah pusat yang bertempat di UPT sendiri maupun diluar kota.
Pelatihan yang dilaksankan diluar kota biasanya merupakan program dari pemerintah pusat. Pelatihan ini tidak hanya diperuntukan untuk para pegawai atau operator UPT Teknologi dan Komunikasi saja, tetapi juga diperuntukan untuk para guru-gugru yang ada di Provinsi Riau. Tetapi tidak semua sekolah yang ada di Provinsi Riau yang mendapatkan pelatihan ini, setiap kabupaten hanya 1 sekolah dan hanya 2 orang guru per sekolah. Salah satu contoh pelatihan yang diberikan kepada guru yaitu pembuatan web site dan blog. Hal ini bertujuan agar para guru memiliki web site dan blog sendiri sehingga dapat berinteraksi dengan jajaran dinas pendidikan kabupaten maupun provinsi dalam rangka menigkatkan mutu pendidikan. Karena guru merupakan sasaran utama dari pemanfaatan IT dalam dunia pendidikan, selain jajaran Dinas pendidikan Provinsi Ria, kabupaten dan kota. Tetapi pelatihan sering terkendala oleh minimnya ketersediaan dana. Karena dalam pelaksanaan pelatihan.

\section{F. KESIMPULAN}

Setelah melakukan penelitian peneliti menyimpulkan strategi penerapan $e$ Government pada UPT teknologi dan komunikasi pendidikan dinas pendidikan Provinsi Riau sudah terlaksana, namun masih belum maksimal, dikarenakan masih ada beberapa program yang belum terlaksana.

\section{DAFTAR PUSTAKA \\ $\underline{\text { Buku }}$}

Creswell, Jhon. W. 2002. Research Design (desain penelitian pendekatan kualitatif dan kuantitatif). KIK Pres: Jakarta. 
David, Fred. R. Terjemahan Paulyn Sulistio dan Harryandi Mahardika, 2006. Strategic Manajement. Salemba Empat, Jakarta.

David, Fred. R. Terjemahan Alexander Sindoro. 2004. Strategic Manajement Konsep Edisi Tujuh. Salemba Empat, Jakarta.

Miles, Mathew B. Dan A. Michel Hubermen. 1992. Analisis Data Kualitatif Buku Sumber Tentang Metode-metode baru. Jakarta : Universitas Indonesia (UI-Press).

Rangkuti, Ferddy. 2006. Analisis SWOT Teknik Pembedahan Kasus Bisnis, Gramedia Pustaka Utama, Jakarta.

\section{Kebijakan}

Instruksi Presiden No. 3 Tahun 2003

Tentang Kebijakan dan Strategi Nasional Pengembangan e-Governmnet. UNDANG-Undang No. 11 Tahun 2008 Tentang Informasi dan Transaksi Elektronik Undang-Undang No. 14 Tahun 2008 Tentang Keterbukaan Informasi Publik merupakan acuan/batasan-batasan dalam penerapan teknologi informasi dan komunikasi di Indonesia. 
DECISION: Jurnal Administrasi Publik

Vol. 1 No. 1, Maret 2019 